\title{
Body mass index in offspring of mothers with diabetes mellitus: follow-up at $2,4,6$, and 8 years of age
}

\author{
Carlos F. Martínez-Cruz ${ }^{1 *}$, Martina A. Guido-Campuzano ${ }^{1}$, Alma M. Ramírez-Maya ${ }^{1}$, \\ Patricia García-Alonso Themann ${ }^{1}$, Adriana Poblano-Alcalá2, Gloria E. López-Navarrete' ${ }^{1}$, and \\ Adrián Poblano²
}

${ }^{1}$ Departamento de Seguimiento Pediátrico, Instituto Nacional de Perinatología Dr. Isidro Espinosa de los Reyes; ${ }^{2}$ Laboratorio de Neurofisiología Cognitiva, Instituto Nacional de Rehabilitación. Mexico City, Mexico

\begin{abstract}
Background: Offspring of mothers with diabetes mellitus (DM) during pregnancy may be at high risk for developmental alterations. This study aimed to identify the effects of maternal pre- and gestational diabetes on the body mass index of infants and children at two, four, six, and eight years of age. Methods: We studied children of mothers with type 1, type 2, and gestational diabetes and a control group. Maternal and neonatal variables were analyzed for associations with children overweight/obesity. Results: Mothers with DM were older than controls (32 \pm 6 vs. $22 \pm 6$ years, $p<0.001$ ). The frequency of preeclampsia in mothers with DM was $28 \%$. Gestational age and weight at birth were lower in infants from the groups of mothers with DM in comparison with controls (32.8 \pm 3.1 vs. $36.4 \pm 2.2$ weeks, $p<0.001$, and 1,637 \pm 600 vs. 2,208 $\pm 518 \mathrm{~g}$, $p<0.001$, respectively). At 8 years of age, $47 \%$ of the offspring of mothers with DM type 2 had overweight/obesity (odds ratio (OR 8.25 ) 95\% confidence interval $(C I) 1.3-51, p=0.01$ ), while $27 \%$ of offspring of mothers with type 1 DM had overweight/obesity, and $10 \%$ of offspring of mothers with gestational diabetes presented overweight/obesity. Conclusions: Offspring of pre-gestational DM mothers have a higher risk to develop overweight/obesity, as was observed with follow-up until school age, for which they require continuous vigilance.
\end{abstract}

Keywords: Diabetes mellitus. Gestational diabetes. Body mass index. Obesity. Overweight.

\section{Índice de masa corporal en hijos de madres con diabetes mellitus: seguimiento a los 2 ,} 4, 6 y 8 años de edad

\section{Resumen}

Introducción: Los hijos de madres con diabetes mellitus durante el embarazo pueden tener un alto riesgo de alteraciones del desarrollo. El objetivo de este estudio fue buscar los efectos de la diabetes pregestacional y gestacional en el índice de masa corporal de niños a los 2, 4, 6 y 8 años de edad. Métodos: Se estudiaron los hijos de madres con diabetes tipo 1,2 y gestacional, así como un grupo control. Se analizaron las variables maternas y neonatales en búsqueda de una asociación con sobrepeso u obesidad en los niños. Resultados: La edad de las madres con diabetes mellitus fue mayor que

\section{Correspondence:}

*Carlos F. Martínez-Cruz

E-mail: drmtzcarlos@yahoo.com.mx

Available online: 17-09-2021

Date of reception: 5-10-2020

Date of acceptance: 2-02-2021

DOI: 10.24875/BMHIM.20000311
Bol Med Hosp Infant Mex. 2021;78(5):395-403

www.bmhim.com

1665-1146/@ 2021 Hospital Infantil de México Federico Gómez. Published by Permanyer. This is an open access article under the CC BY-NC-ND license (http://creativecommons.org/licenses/by-nc-nd/4.0/). 
la del grupo control (32 \pm 6 vs. $22 \pm 6$ años, $p<0.001$ ). La frecuencia de preeclampsia en las madres con diabetes mellitus fue del $28 \%$. La edad gestacional y el peso al nacer fueron menores en los hijos de las madres con diabetes en comparación con los controles (32.8 \pm 3.1 vs $36.4 \pm 2.2$ semanas, $p<0.001$, y 1,637 \pm 600 vs. 2,208 \pm 518 g, $p<0.001$, respectivamente). A los 8 años, el 47\% de los hijos de madres con diabetes tipo 2 tuvieron sobrepeso u obesidad (RM: 8.25; intervalo de confianza del 95\%: 1.3-51; $p=0.01$ ), frente al $27 \%$ de los hijos de madres con diabetes tipo 1 y el $10 \%$ de los hijos de madres con diabetes gestacional. Conclusiones: Los hijos de madres con diabetes pregestacional presentan un mayor riesgo de desarrollar sobrepeso u obesidad, como se observó en el seguimiento hasta la edad escolar, por lo que requieren una vigilancia continua.

Palabras clave: Diabetes mellitus. Diabetes gestacional. Índice de masa corporal. Sobrepeso. Obesidad.

\section{Introduction}

Diabetes mellitus (DM) during pregnancy may be associated with poor maternal and perinatal outcomes'. Due to improvements in medical care, offspring of diabetic mothers have higher survival rates, although a greater risk of overweight/obesity $(\mathrm{O} / \mathrm{O})$ during their lifetime. However, the pathophysiological mechanisms of these alterations have not been fully understood².

Since $\mathrm{O} / \mathrm{O}$ are among the most important nutritional problems in the world, their causes require further research as prevention can help improve the quality of life in children and even in adult life. It is necessary to identify what risk factors favor the development of childhood obesity to decrease the high percentage of children with $\mathrm{O} / \mathrm{O}^{3}$.

DM during pregnancy is associated with increased fetal growth, possibly due to the storage of more fetal fat mass and altered hormone levels, which result in hyperglycemia, hyperinsulinemia, and a high leptin synthesis ${ }^{4}$. Pregestational DM (PDM) and gestational DM (GDM) can also modify the fetal epigenome, influencing the expression of genes that drive to accumulation of body fat or related metabolism alterations ${ }^{5}$.

Mothers with PDM have a chronic metabolic disorder, and they may present hyperglycemia since the beginning of pregnancy. Conversely, mothers with GDM develop hyperglycemia in the second or third trimester of pregnancy, but the complications found have been described as not severe ${ }^{6}$. However, not all physicians agree with this statement. It has been shown that strict glycemic control during early gestation reduces the prevalence of some complications of the mother-child binomial $^{7}$. As we cannot assume that PDM and GDM have the same effects on fetal development and the same long-term outcomes in offspring, it is essential to study the effects of both conditions on the offspring of these mothers.

This research hypothesized that fetal hyperglycemia reorganizes hypothalamic centers for hunger and results in super-expression of child search for food and later in $\mathrm{O} / \mathrm{O}$. This study aimed to analyze the effect of differential distribution of body mass index (BMI) as a parameter of nutritional status in the offspring of mothers with PDM or GDM at 2, 4, 6, and 8 years of age at pediatric follow-up. Maternal and neonatal variables were analyzed, looking for possible associations with O/O.

\section{Methods}

\section{Subjects}

We designed and conducted a prospective study. Measurements of BMI were carried out at 2, 4, 6, and 8 years of age. For observations, four groups were studied: offspring from mothers with type $1 \mathrm{DM}$, offspring from mothers with type $2 \mathrm{DM}$, and offspring from mothers with GDM. A control group (CG) with infants from healthy pregnancies was also included. Inclusion criteria for mothers with DM and their infants were children from mothers with DM born at our institution and who accepted to participate in the follow-up program. Children from mothers with DM were part of the multidisciplinary pediatric follow-up of infants at high risk. The CG was formed with low-risk mother-child binomials: mothers with no history of DM, hypertension, or infections; intake of anticonvulsants, anti-depression, anti-coagulant, or other drugs during pregnancy; neither multiple pregnancies nor other alterations. Inclusion criteria for control children were no genetic syndromes, congenital malformations, severe complications at delivery or during the neonatal period, sensory or neurological sequelae, or any other. In addition, they must also belong to our pediatric follow-up clinic.

The research committee of the institutions accepted this protocol. The parents were informed of the importance of children's participation and the purposes and benefits of the research. Informed consent was 
requested and signed according to the Helsinki declaration.

\section{Studied variables}

Our hospital is a specialized institution in human reproduction medicine and a reference center for high-risk pregnancies. For these reasons, pregnancies complicated with DM are one of the followed conditions. The following variables were studied in mothers: diagnosis and type of DM based on the recommendations of the American Diabetes Association criteria $^{8}$, age during pregnancy, insulin dependence, use of prenatal steroids for fetal pulmonary maturation, delivery method, history of morbidities, such as preeclampsia and others.

The variables studied in infants were gestational age at birth (weeks), birth weight (grams), Apgar score at 1 and 5 minutes, sex, morbidities during the neonatal period, respiratory distress syndrome, application of pulmonary surfactant, history of broncho-pulmonar dysplasia according to Northway's criteria ${ }^{9}$, neonatal hypoglycemia (capillary glycemia $<45 \mathrm{mg} / \mathrm{dl}$ ), hypocalcemia (total Ca serum $<8 \mathrm{mg} / \mathrm{dl}$ in term newborns and $<7 \mathrm{mg} / \mathrm{dl}$ in preterm newborns), intraventricular hemorrhage (determined by transfontanelar ultrasonography after Volpe's classification $\left.{ }^{10}\right)$, neonatal hyperbilirubinemia (managed with phototherapy or exchange transfusion).

\section{Anthropometric measures}

- Weight was determined in children by a certified nutritionist at every appointment (at 2, 4, 6, and 8 years of age) with standardized techniques ${ }^{11}$ : during the mornings, with the child wearing only underwear. We used a Seca weight scale (Hamburg, Germany) model 703, with a capacity of $150 \mathrm{~kg}$ and a precision of $0.5 \mathrm{~g}$, and integrated telescopic rule, model 220 (measurement range: $60-200 \mathrm{~cm}$, minimum precision of $0.5 \mathrm{~cm}$ ).

- Height was determined with the child standing erect with the back against the stadimeter, facing forward, with the Frankfurt plane parallel to the ground. Heels, spine, and occiput were supported on a rigid plane, and arms were extended along the trunk.

- BMI was calculated according to the international known equation $=$ weight $(\mathrm{kg}) /$ height $^{2}\left(\mathrm{~m}^{2}\right)$. We used the Center for Disease Control tables for gender and age to classify children's data. We considered measurements as adequate when found between the $10-85^{\text {th }}$ percentiles. $\mathrm{BMI}<10^{\text {th }}$ percentile was classified as low weight; BMI $86-95^{\text {th }}$ percentiles were identified as overweight, and $\mathrm{BMI}>95^{\text {th }}$ percentile was classified as obesity ${ }^{12,13}$. The nutritional intervention for these children was carried out by certified nutritionists and pediatricians and was continuously verified throughout their follow-up period.

\section{Follow-up and surveillance}

We closely followed the infants' and children's food intake and exercise activities throughout the study. The infants' appointments were every 3 months during the first year of life, every 6 months in the next 5 years, and every year until 8 years of age. The parents received many academic presentations on how to monitor children's food intake and seek medical consultation in the case of illness or doubts about food intake. During the appointments, we asked the parents about food intake and exercise schedules according to age and gender and the abuse of snacks with high carbohydrates and fats. Bad habits regarding excessive consumption of candies, sodas, hypercaloric snacks intake, or sedentary lifestyle were corrected.

\section{Statistical analysis}

Continuous data were presented as means and standard deviations. The variance homogeneity test was performed with Levene's test. For comparison of means, we used the one-way analysis of variance (ANOVA) with Scheffé's post-hoc test (for unbalanced groups). Categorical variables were presented as percentages and analyzed using the $\chi^{2}$ test.

For the BMI analysis, obesity and overweight were combined. Odds ratios (OR) were calculated for each group in each age period. The same analysis was performed for the low weight $\left(<10^{\text {th }}\right.$ percentile). A $p$-value $<0.05$ was considered significant.

\section{Results}

\section{Overall characteristics}

From 8,993 children recruited for the follow-up, $323(3.5 \%)$ fulfilled the inclusion criteria and were born from mothers with type $1 \mathrm{DM}, 2 \mathrm{DM}$, or GDM, and CG. From these children, 266 (2.9\%) corresponded to some type of DM during pregnancy, with the following distribution: type $1 \mathrm{DM}, \mathrm{n}=95$ (29.4\%); type $2 \mathrm{DM}$, 
Table 1. Alterations in mothers with diabetes mellitus and control group

\begin{tabular}{|c|c|c|c|c|c|c|}
\hline Variable & $\begin{array}{c}\text { Type } 1 \text { DM } \\
(\mathrm{n}=95) \\
(29.4 \%)\end{array}$ & $\begin{array}{c}\text { Type } 2 \text { DM } \\
(n=70) \\
(21.7 \%)\end{array}$ & $\begin{array}{l}\text { Gestational DM } \\
\qquad \begin{array}{c}(\mathrm{n}=101) \\
(31.3 \%)\end{array}\end{array}$ & $\begin{array}{c}\text { Control group } \\
(\mathbf{n}=\mathbf{5 7}) \\
(17.6 \%)\end{array}$ & $\begin{array}{c}\text { Total } \\
(\mathrm{n}=323) \\
(100 \%)\end{array}$ & $p$-values \\
\hline Preeclampsia & $27(8.4 \%)$ & $27(8.4 \%)$ & $36(11.1 \%)$ & $3(0.9 \%)$ & $93(28.8 \%)$ & 0.001 \\
\hline $\begin{array}{l}\text { Use of prenatal } \\
\text { steroids }\end{array}$ & $23(7.1 \%)$ & $21(6.5 \%)$ & $39(12.1 \%)$ & $3(0.9 \%)$ & $86(26.6 \%)$ & 0.001 \\
\hline Cesarean & $85(26.3 \%)$ & $66(20.4 \%)$ & $97(30 \%)$ & $55(17 \%)$ & $303(93.8 \%)$ & 0.19 \\
\hline Deceased mothers & $9(2.8 \%)$ & $3(0.9 \%)$ & $4(1.2 \%)$ & $0(0.0 \%)$ & $16(5 \%)$ & 0.06 \\
\hline
\end{tabular}

$\mathrm{n}=70$ (21.7\%); GDM, n= 101 (31.3\%); while CG was formed with 57 infants (17.6\%).

\section{Maternal variables}

The mean age of mothers with DM was significantly higher than control mothers (32 \pm 6 vs $22 \pm 6$ years, $p<0.001)$. The number of gestations was distributed as follows: first pregnancy (primigravida), $n=115$ (35.6\%); second gestation, $\mathrm{n}=95$ (29.9\%); third gestation, $n=51$ (15.7\%); fourth gestation, $n=34$ (10.6\%); fifth gestation or more, $\mathrm{n}=28(8.7 \%)$.

Frequency of pre-eclampsia in mothers with DM during pregnancy was $27.9 \%(p<0.001)$ and was distributed as follows: pre-eclampsia/type $1 \mathrm{DM}, 7.1 \%$ (odds ratio $(\mathrm{OR}) 7.1 ; 95 \%$ confidence interval $(\mathrm{Cl})=$ 2-24.8, $p<0.001)$; pre-eclampsia/type 2 DM, 11.3\% (OR 11.3; 95\% Cl = 3.2-39.7, $p<0.001$ ); pre-eclampsia/ GDM, 9.9\% (OR 9.9; 95\% Cl = 2.9-34, $p<0.001$ ). In addition, 16 mothers with DM (5\%) died at some point of follow-up, most of them from the type $1 \mathrm{DM}$ group ( $n=9,2.8 \%$ ) (Table 1).

\section{Neonatal variables}

The mean gestational age at birth was significantly lower for infants of mothers with DM than the CG (32.8 \pm 3.1 vs. $36.4 \pm 2.2$ weeks, $p<0.001$ ), and $82 \%$ were late preterm infants (32-37 weeks) $(p<0.001)$. Birthweight was significantly lower for children of mothers with DM than CG $(1,637 \pm 600$ vs. $2,208 \pm 518 \mathrm{~g}$, $p<0.001$ ) (Table 2). Birthweight classification showed a high frequency of eutrophic preterm infants $(64.9 \%$, $\mathrm{n}=209$ ), followed by hypotrophic preterm infants $(15.5 \%, n=50)$ (Table 3). Additionally, 94 infants were born by cesarean section.

\section{Neonatal morbidity}

Regarding neonatal morbidity, $26 \%$ of children received pulmonary maturation regimens with prenatal steroids. Pulmonary surfactant was used in $28.9 \%$ of infants, significantly more frequent in offspring of mothers with DM $(p<0.001)$. Hypoglycemia and hypocalcemia during the neonatal period were present in $6.5 \%$ and $2.5 \%$, respectively. The main neonatal morbidities presented as follows: hyperbilirubinemia (43.3\%), intraventricular hemorrhage $(9.6 \%)$, and bronchopulmonary dysplasia (12.4\%), which were significantly more frequent in infants from DM mothers (Table 3).

\section{$B M I$ and nutrition status in children}

We found an adequate $\mathrm{BMI}$ in $58 \%$, overweight in $6.5 \%$, and obesity in $3.2 \%$ in children at 2 years of age (Figure 1). O/O was present in children of mothers with type $1 \mathrm{DM}$ in $8.7 \%$, type $2 \mathrm{DM}$ in $13.6 \%$, GDM in $8.2 \%$, and $C G$ in $6 \%$, with no significant differences between groups.

At 4 years of age, $\mathrm{O} / \mathrm{O}$ was observed in offspring of mothers with type $1 \mathrm{DM}$ in $15.1 \%$, type $2 \mathrm{DM}$ in $15.2 \%$, GDM in $5.2 \%$, and CG in $6 \%$, with no significant differences among groups (Figure 1).

We found an adequate BMI of $47.6 \%$ at 6 years of age. We observed an increase in the frequency of overweight $(10.6 \%)$ and obesity (11\%): O/O was present in children of mothers with type $1 \mathrm{DM}$ in $31.1 \%$; type $2 \mathrm{DM}$ in $14.8 \%$; GDM in $16.7 \%$; and the CG in $17.2 \%$, with no significant differences (Figure 2).

At 8 years of age, $\mathrm{O} / \mathrm{O}$ occurred in children of mothers with type $1 \mathrm{DM}$ in $26.9 \%$ ( $p=0.21)$; type $2 \mathrm{DM}$ in $47.4 \%(p=0.01)$; GDM in $10 \%(p=0.77)$; while in the CG, O/O was observed in $10 \%$ of the children. These findings mean that 2.5 of each ten infants from mothers 
Table 2. General characteristics in offspring of mothers with diabetes mellitus and control group

\begin{tabular}{|c|c|c|c|c|c|c|}
\hline \multirow[t]{2}{*}{ Variable } & $\begin{array}{c}\text { Type } 1 \text { DM } \\
(n=95) \\
(29.4 \%)\end{array}$ & $\begin{array}{c}\text { Type } 2 \text { DM } \\
(n=70) \\
(21.7 \%)\end{array}$ & $\begin{array}{l}\text { Gestational DM } \\
\qquad(\mathrm{n}=101) \\
(31.3 \%)\end{array}$ & $\begin{array}{c}\text { Control group } \\
(\mathrm{n}=\mathbf{5 7}) \\
(17.6 \%)\end{array}$ & $\begin{array}{c}\text { Total } \\
(\mathrm{n}=323) \\
(100 \%)\end{array}$ & $\begin{array}{c}\text { ANOVA } \\
p \text {-values }\end{array}$ \\
\hline & Mean \pm SD & Mean \pm SD & Mean \pm SD & Mean \pm SD & Mean \pm SD & \\
\hline Gestational age (weeks) & $33.1 \pm 2.8$ & $33.4 \pm 3.1$ & $32.0 \pm 2.5$ & $36.4 \pm 2.2$ & $33.5 \pm 3.1$ & 0.001 \\
\hline Birthweight (g) & $1660 \pm 563$ & $1745 \pm 690$ & $1507 \pm 547$ & $2208 \pm 518$ & $1727 \pm 626$ & 0.001 \\
\hline Maternal age (years) & $31 \pm 6$ & $34 \pm 5$ & $33 \pm 6$ & $22 \pm 6$ & $31 \pm 7$ & 0.001 \\
\hline Apgar score (1 min) & $6 \pm 2$ & $6 \pm 2$ & $6 \pm 2$ & $6 \pm 2$ & $6 \pm 2$ & 0.49 \\
\hline Apgar score (5 min) & $8 \pm 1$ & $8 \pm 1$ & $8 \pm 1$ & $8 \pm 1$ & $8 \pm 2$ & 0.14 \\
\hline Male & $50(16 \%)$ & $34(10 \%)$ & $53(16 \%)$ & $28(8.7 \%)$ & $165(51 \%)$ & \\
\hline Female & $45(14 \%)$ & $36(11 \%)$ & $48(15 \%)$ & $29(9.3 \%)$ & $158(49 \%)$ & $0.93^{*}$ \\
\hline Term infant & $6(1.9 \%)$ & $11(3.4 \%)$ & $11(3.4 \%)$ & $30(9.3 \%)$ & $58(18 \%)$ & \\
\hline Premature infant & $89(27.6 \%)$ & $59(18.3 \%)$ & 90 (27.9\%) & $27(8.4 \%)$ & $265(82 \%)$ & $0.001^{*}$ \\
\hline
\end{tabular}

DM, diabetes mellitus; ANOVA, analysis of variance; SD, standard deviation. ${ }^{*} \chi^{2}$.

Table 3. Neonatal morbidity in offspring of mothers with diabetes mellitus and controls

\begin{tabular}{|c|c|c|c|c|c|c|}
\hline Variable & $\begin{array}{c}\text { Type } 1 \text { DM } \\
(n=95) \\
(29.4 \%)\end{array}$ & $\begin{array}{c}\text { Type } 2 \text { DM } \\
(n=70) \\
(21.7 \%)\end{array}$ & $\begin{array}{l}\text { Gestational DM } \\
\qquad \begin{array}{c}(\mathrm{n}=101) \\
(31.3 \%)\end{array}\end{array}$ & $\begin{array}{c}\text { Control group } \\
(n=57) \\
(17.6 \%)\end{array}$ & $\begin{array}{c}\text { Total } \\
(\mathrm{n}=323) \\
(100 \%)\end{array}$ & $p$-values \\
\hline Eutrophic term infant & $7(2.2 \%)$ & $8(2.5 \%)$ & $6(1.9 \%)$ & $14(4.3 \%)$ & $35(10.9 \%)$ & 0.002 \\
\hline Hypotrophic term infant & $1(0.3 \%)$ & $3(0.9 \%)$ & $3(0.9 \%)$ & $16(5.0 \%)$ & $23(7.1 \%)$ & 0.001 \\
\hline Hipertrophic premature infant & $2(0.6 \%)$ & $2(0.6 \%)$ & $1(0.3 \%)$ & $1(0.3 \%)$ & $6(1.8 \%)$ & 0.84 \\
\hline Eutrophic premature infant & $63(19.6 \%)$ & $49(15.2 \%)$ & $74(23 \%)$ & $23(7.1)$ & $209(64.9 \%)$ & 0.001 \\
\hline Hypotrophic premature infant & $22(6.8 \%)$ & $8(2.5 \%)$ & $17(5.3 \%)$ & $3(0.9 \%)$ & $50(15.5 \%)$ & 0.02 \\
\hline Pulmonary surfactant use & $25(7.9 \%)$ & $21(6.7 \%)$ & $44(14 \%)$ & $1(0.3 \%)$ & $91(28.9 \%)$ & 0.001 \\
\hline Neonatal hypoglycemia & $7(2.2 \%)$ & $8(2.5 \%)$ & $4(1.4 \%)$ & $2(0.6 \%)$ & $21(6.5 \%)$ & 0.18 \\
\hline Neonatal hypocalcemia & $2(0.6 \%)$ & $6(1.9 \%)$ & $0(0 \%)$ & $0(0 \%)$ & $8(2.5 \%)$ & 0.002 \\
\hline Neonatal hyperbilirubinemia & $51(15.8 \%)$ & $32(9.9 \%)$ & $52(16.1 \%)$ & $5(1.5 \%)$ & $140(43.3 \%)$ & 0.001 \\
\hline Intraventricular hemorrhage & $12(3.7 \%)$ & $11(3.4 \%)$ & $7(2.2 \%)$ & $1(0.3 \%)$ & $31(9.6 \%)$ & 0.03 \\
\hline Bronchopulmonary dysplasia & $14(4.3 \%)$ & $10(3.1 \%)$ & $16(5 \%)$ & $0(0 \%)$ & $40(12.4 \%)$ & 0.02 \\
\hline
\end{tabular}

DM, diabetes mellitus.

$p=\chi^{2}$.

with type $1 \mathrm{DM}$ had $\mathrm{O} / \mathrm{O}$. One of every two children of mothers with type $2 \mathrm{DM}$ had O/O $(47.4 \%$, OR $8.25 ; 95 \%$ $\mathrm{Cl} 1.3-51, p=0.01$ ) (overweight $31.6 \%$, obesity $15.8 \%$ ). One of 10 children of mothers with GDM and from the CG had O/O.
Administration of prenatal steroids for lung maturation was not associated with overweight or obesity. Children with low BMI (percentile $<10^{\text {th }}$ ) were always present in all groups with a frequency of $31.5 \%$ (Figures 1 and 2). 


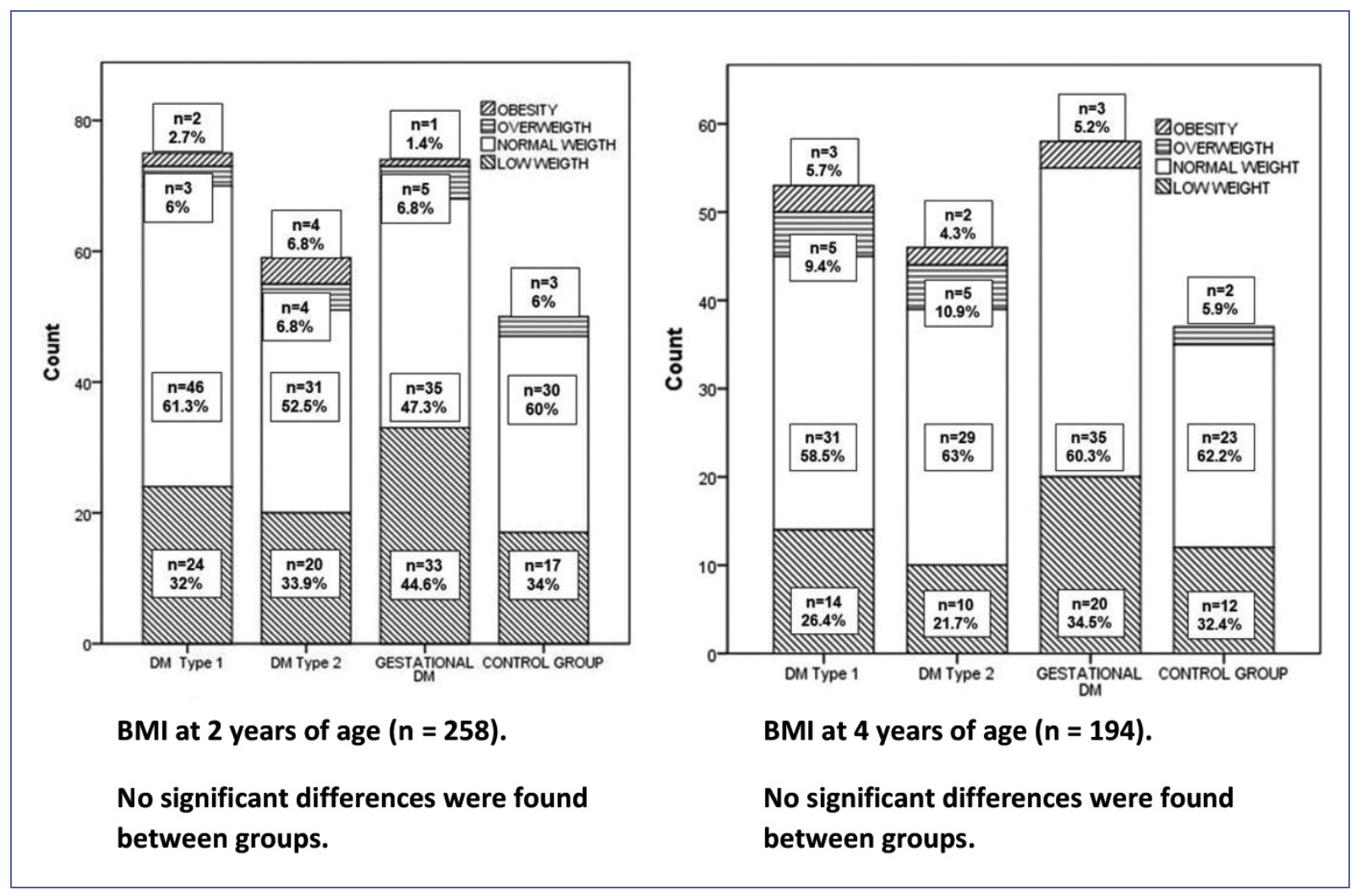

Figure 1. Nutritional status of children at 2 and 4 years of age according to the percentage of distribution of body mass index (BMI) in offspring of mothers with diabetes mellitus (DM) and controls.

\section{Discussion}

\section{Main findings}

We found that one of two children from mothers with type $2 \mathrm{DM}$ could have a higher frequency of $\mathrm{O} / \mathrm{O}$ at 8 years of age. Prenatal steroids administration for lung maturation was not associated with $\mathrm{O} / \mathrm{O}$. We also found a high frequency of preeclampsia in mothers with DM, mainly in mothers with type $2 \mathrm{DM}$, with high mortality in mothers with type $1 \mathrm{DM}$.

\section{Clinical relevance}

Our data show that children from mothers with DM during pregnancy have a lamentably and impressive high frequency of $\mathrm{O} / \mathrm{O}$. This result must alert physicians to perform a closer follow-up of these children in managing food intake and exercise promotion to reach a better quality of life. Prenatal steroids for lung maturation could be administrated safely with no risk for $\mathrm{O} / \mathrm{O}$ in children. Furthermore, obstetricians must pay attention to mothers with DM because they could develop a high frequency of preeclampsia.

\section{Maternal morbidity and mortality}

Worldwide, the prevalence of PDM and GDM is increasing due to higher rates of $\mathrm{O} / \mathrm{O}$ in women and an older maternal reproductive age ${ }^{1,2}$. Glycemic control, diet, exercise, and early prenatal care in pregnant women with DM in our institution was carried out by a multidisciplinary team with gynecologists, obstetricians, maternal-fetal medicine specialists, endocrinologists, nutritionists, social workers, psychologists, and other specialists, suggesting that even more control is needed because alterations still occur with significant frequency.

The frequency of preeclampsia in mothers with DM was high (28\%)-with a higher risk in mothers with type $2 \mathrm{DM}-$, which is considered one of the leading causes of preterm birth, maternal-fetal morbidity, and mortality ${ }^{14,15}$. For example, Yu et al. found that preeclampsia has a higher incidence in women with type 1 DM than the non-diabetic population (20\% vs. $5 \%)^{16}$. The mechanisms that contribute to this effect are not well established. High glucose levels during pregnancy with DM can trigger intracellular changes 


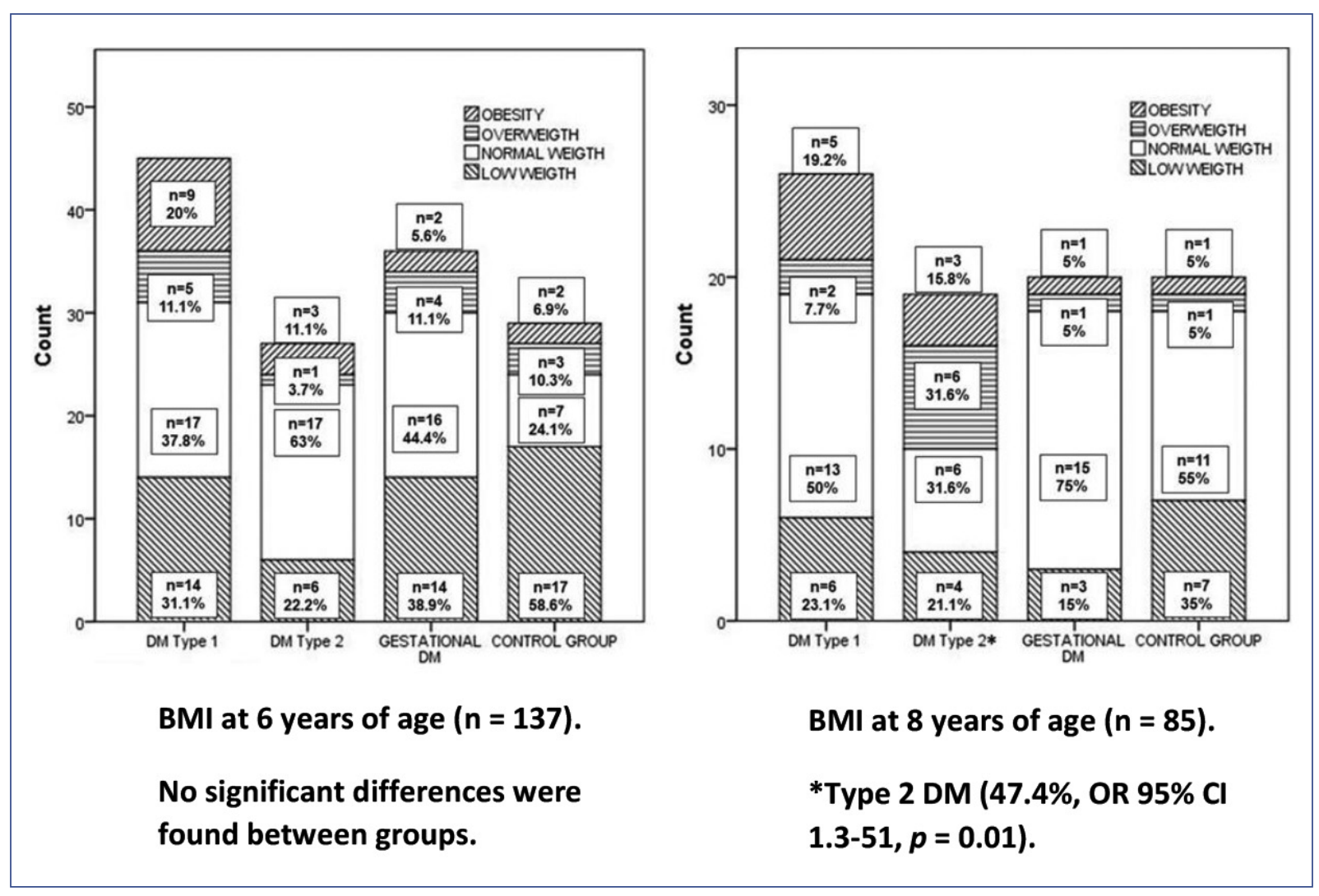

Figure 2. Nutritional status of children at 6 and 8 years of age according to the percentage of distribution of body mass index (BMI) in offspring of mothers with diabetes mellitus (DM) and controls.

that cause cytotrophoblast dysfunction, predisposing to abnormal placental vascular development and preeclampsia.

Five percent of mothers with DM died during follow-up, with higher mortality of mothers with type 1 DM, possibly due to the chronic condition and complications; however, mothers with type $2 \mathrm{DM}$ and GDM also presented significant mortality, suggesting the need for a close and effective prenatal control.

\section{Infantile morbidity and mortality}

During the neonatal period in offspring, morbidities were mainly hyperbilirubinemia, intra-ventricular hemorrhage, and bronchopulmonar dysplasia, which correspond to alterations associated with premature birth, and prevailed significantly in the groups of mothers with DM. Some authors suggest that optimal perinatal control could minimize these morbidities, although it will be difficult to abolish them completely ${ }^{6}$.

\section{Children's BMI}

An adequate BMI (59\%) predominated in all the studied groups and periods. Unhealthy weight (overweight, obesity, and low-weight) was present in each group and all periods, with a clear tendency of $\mathrm{O} / \mathrm{O}$ increase with age and an inverse trend for low-weight.

Overweight predominated in children of 2 and 4 years and increased in children of 6 and 8 years. This finding suggests that early overweight precedes obesity at school age. Thus, the proportion of overweight in pre-school children deserves attention because it is an early high-risk indicator of the influence of $\mathrm{O} / \mathrm{O}$ at 4 years of age, which progresses to a higher proportion of children with obesity at school age, with a high proportion in the offspring of mothers with types 1 and $2 \mathrm{DM}$. This fact is important from a prevention point of view since it represents a window of opportunity to modify the natural history of the appearance of $\mathrm{O} / \mathrm{O}$ and an excellent time to implement primary prevention programs. 
Deierlein et al. found that fetal exposure to maternal glucose concentrations in the high normal range was associated with the development of $\mathrm{O} / \mathrm{O}$ in offspring at 3 years of age, regardless of pre-gestational $\mathrm{BMI}^{7}$. This result is consistent with our data because predictive indicators of $\mathrm{O} / \mathrm{O}$ in children are potentially preventable. Therefore, early identification is crucial because it progresses with age and is characterized by an imbalance between intake and energy expenditure.

Studies that evaluated unhealthy weight in offspring of mothers with DM have reported inconsistent associations. The Northwestern University Diabetes in Pregnancy Study reported that weight in offspring of mothers with GDM increased after 5 years of age and that $50 \%$ of the children had a weight $>90$ percentile at 8 years of age ${ }^{17}$. We found similar results, although in the offspring of mothers with type $2 \mathrm{DM}$ (one of two with $\mathrm{O} / 0$ ). This finding is consistent with a new report in children of 2-5 years of age, where $\mathrm{O} / \mathrm{O}$ was observed in two of ten of them ( $17 \%$ and $5.8 \%$, respectively $)^{18}$. However, the frequency of $\mathrm{O} / \mathrm{O}$ in offspring of mothers with DM is higher. Obesity is also observed worldwide, and this trend likely results from changes in nutritional behaviors and physical activity patterns. Evidence links dietary and lifestyle factors, which invade domestic and school environments with the risk of $\mathrm{O} / \mathrm{O}^{19}$.

In the present study, the children of mothers with GDM in all the analyzed periods showed O/O with no significant differences compared to the CG. At 8 years of age, only one of 10 children from a mother with GDM showed O/O. Both GDM and CG stand out for the tendency to progressively increase $\mathrm{O} / \mathrm{O}$ during the studied period. However, other studies conducted in China found that maternal GDM increased cardio-metabolic risk in early childhood at 8 years of age but not at 15 years of age $^{20}$. Another study suggested that the $\mathrm{O} / \mathrm{O}$ in offspring is explained mainly by maternal pre-pregnancy $\mathrm{BMI}^{21}$. As these data contrast with our results, more research is needed to clarify this controversy.

Offspring of mothers with GDM showed the same percentage of $\mathrm{O} / \mathrm{O}$ as children of the $\mathrm{CG}$. This finding suggests that the consequences of long-standing changes induced by DM are more adverse in these children. Thus, fewer complications were present in infants from the newly acquired DM in pregnancy. However, more studies are needed to confirm the effect of GDM on childhood O/O. By the experience of the study, we suggest that the problem of childhood O/O might be related not only to pathological or genetic maternal history but also with environmental factors such as demographic and family factors, eating and exercise habits, socioeconomic condition, maternal $\mathrm{BMI}$, maternal education, and nutrition education ${ }^{2,5}$.

The increased frequency of $\mathrm{O} / \mathrm{O}$ in offspring of mothers with type $2 \mathrm{DM}$ at 8 years of age is noticeable compared with the other groups ${ }^{4}$. A possible explanation may be that these mothers had a higher genetic predisposition, worse nutritional habits, and fewer sports activities that influenced their children's development.

By the time they reach childbearing age, young women with DM or carbohydrate intolerance may perpetuate a vicious intergenerational cycle ${ }^{22}$. In terms of postnatal interventions, breastfeeding seems to have a protective effect against DM. The beneficial effects appear to be through bioactive nutrients found only in breast milk: higher protein content and a slower postnatal growth pattern than formula-fed infants ${ }^{23}$. In a retrospective study, Crume et al. analyzed the impact of breastfeeding in infant adiposity after PDM and GDM. They reported that breastfeeding for 6 months or more compared to $<6$ months was associated with significantly lower BMI, waist circumference, and visceral and subcutaneous adipose tissue at 6-13 years of age ${ }^{24}$.

Conversely, the percentage of offspring of mothers with DM with low weight was $31 \%$. The frequency of low-weight infants was constantly maintained in all groups and at all ages ${ }^{6,17}$. In Mexico, low-weight in infants is a long-standing food-nutritional problem that has not been solved yet and may be present in this studied sample.

\section{Proposed hypothesis}

Our results suggest fetal metabolic programming in offspring of mothers with DM that reorganizes fetus for hyperglycemia. After birth, children developed particular hunger for sugars and fats. Around 8 years of age, when children are more active in food search, they developed O/O. However, it would be hard to test this hypothesis without considering the transmission of learned lifestyles. This idea is in partial agreement with other authors ${ }^{25}$ and deserves more research in future studies.

\section{Limitations and strengths}

Sample losses through time due to desertion were $18.2 \%$ at 8 years of follow-up. Confusing variables such as pre-gestational maternal obesity, poor nutrition habits, sedentary lifestyle, socioeconomic and educational level, and short breastfeeding must be controlled. Pre-, 
peri-, and postnatal interventions must be considered in reducing the risk of type $2 \mathrm{DM}$, obesity, and cardiovascular disease in offspring. As polymorphisms associated with overweight/obesity were not searched, they cannot be ruled out. Despite these facts, our results are significant and reflect an increasing public health concern.

Mothers with DM during pregnancy were found at high risk for preeclampsia development. DM during pregnancy also represents a long-term high-risk for $\mathrm{O} / \mathrm{O}$ in offspring at 8 years of age. Our data cautiously suggests fetal metabolic programming for hyperglycemia in children with mothers with PDM.

\section{Ethical disclosures}

Protection of human and animal subjects. The authors declare that no experiments were performed on humans or animals for this study.

Confidentiality of data. The authors declare that they have followed the protocols of their work center on the publication of patient data.

Right to privacy and informed consent. The authors have obtained the written informed consent of the patients or subjects mentioned in the article. The corresponding author has this document.

\section{Conflicts of interest}

The authors declare no conflict of interest.

\section{Funding}

None.

\section{References}

1. Danaei G, Finucane MM, Lu Y, Singh GM, Cowan MJ, Paciorek CJ, et al. National, regional, and global trends in fasting plasma glucose and diabetes prevalence since 1980: systematic analysis of health examination surveys and epidemiological studies with 370 country-years and $27 \mathrm{mi}-$ Ilion participants. Lancet. 2011;378:31-40.
2. Kim SY, England JL, Sharma JA, Njoroge T. Gestational diabetes mellitus and risk of childhood overweight and obesity in offspring: a systematic review. Exp Diabetes Res. 2011;2011:541308.

3. Kuh D, Hardy R, Chaturvedi N, Wadsworth ME. Birth weight, childhood growth and abdominal obesity in adult life. Int J Obes Relat Metab Disord. 2002;26:40-7

4. Dabelea $\mathrm{D}$. The predisposition to obesity and diabetes in offspring of diabetic mothers. Diabetes Care. 2007;30:169-74.

5. Lehnen $\mathrm{H}$, Zechner $\mathrm{U}$, Haaf $\mathrm{T}$. Epigenetics of gestational diabetes mellitus and offspring health: the time for action is in early stages of life. Mol Hum Reprod. 2013:19:415-22.

6. Xiong X, Saunders LD, Wang FL, Demianczuk NN. Gestational diabetes mellitus: prevalence, risk factors, maternal and infant outcomes. Int $J$ Gynecol Obstet. 2001;75:221-8.

7. Deierlein AL, Siega-Riz AM, Chantala K, Herring AH. The association between maternal glucose concentration and child BMI at age 3 years. Diabetes Care. 2011;34:480-4.

8. American Diabetes Association. Classification and diagnosis of diabetes. Diabetes Care. 2019;42:7-12.

9. Bancalari E, Wilson-Costello D, Iben SC. Management of infants with bronchopulmonary dysplasia in North America. Early Hum Dev. 2005:81:171-9.

10. Volpe JJ. Intraventricular hemorrhage in the premature infant-current concepts. Part I. Ann Neurol. 1989;25:3-11.

11. Lohman TG, Roche AF, Martorell R. Anthropometric standardization reference manual. Champaign (IL): Human Kinetics Books; 1988.

12. Marks GC, Habicht JP, Mueller WH. Reliability, dependability, and precision of anthropometric measurements. The second national health and nutrition examination survey 1976-1980. Am J Epidemiol. 1989;130:578-87.

13. Kuczmarski RJ, Ogden CL, Guo SS, Grummer-Strawn LM; Flegal KM, Mei Z, et al. 2000 CDC Growth Charts for the United States: methods and development. Vital Health Stat 11. 2002;246:1-190.

14. Kalagiri RR, Vora N, Wilson JL, Afroze SH, Raju VN, Govande V, et al. Diabetes and preeclampsia affecting pregnancy: a retrospective cross-sectional study. J Investig Med. 2018;66:728-32.

15. Roberts JM, Redman CW. Preeclampsia: more than pregnancy-induced hypertension. Lancet. 1993;341:1447-51.

16. Yu Y, Jenkins AJ, Nankervis AJ, Hanssen FK, Scholz H, Henriksen T, et al. Anti-angiogenic factors and preeclampsia in type 1 diabetic women. Diabetologia. 2009;52:160-8.

17. Silverman BL, Rizzo T, Green OC, Cho NH, Winter RJ, Ogata ES, et al. Long-term prospective evaluation of offspring of diabetic mothers. Diabetes. 1991;40:121-5.

18. Ogden CL, Carroll MD, Lawman HG, Fryar CD, Kruzson-Moran D, Kit BK, et al. Trends in obesity prevalence among children and adolescents in the United States, 1988-1994 through 2013-2014. JAMA. 2016;315:2292-9.

19. Cockrell-Skinner A, Ravanbakht SN, Skelton JA, Perrin EM, Amstrong SC. Prevalence of obesity and severe obesity in US children, 1999-2016. Pediatrics. 2018;141: e20173459.

20. Tam WH. The long-term effect of maternal gestational diabetes to both the mothers and their offspring [Thesis]. Hong Kong: The Chinese University of Hong Kong; 2012.

21. Shi X, Wang D, Lin M, Su W, Wang L, Xiao F, et al. Maternal gestational diabetes mellitus and offspring body mass index from 1 to 4 years. Endocr Pract. 2020;26:619-26.

22. Pettitt DJ, Nelson RG, Saad MF, Bennett PH, Knowler WC. Diabetes and obesity in the offspring of Pima Indian women with diabetes during pregnancy. Diabetes Care.1993;16:310-4.

23. Stewart A, Malhotra A. Gestational diabetes and the neonate: challenges and solutions. Res Report Neonatol. 2015;2015:31-9.

24. Crume TL, Ogden L, Maligie M, Sheffield S, Bischoff KJ, McDuffie R, et al. Long-term impact of neonatal breastfeeding on childhood adiposity and fat distribution among children exposed to diabetes in utero. Diabetes Care. 2011;34:641-5

25. Ramírez-Velez R. [In utero fetal programming and its impact on health in adulthood]. Endocrinol Nutr. 2012;59:383-93. 